\title{
Soft Skills Workshops with External Trainers: Getting Them Right
}

\author{
TROY B. WIWCZAROSKI ${ }^{1}$ - BORKA RICHTER ${ }^{2}$
}

ABSTRACT

Soft skills development workshops can serve multinational organizations towards the improvement of internal communication between employees of various language backgrounds attempting to collaborate on tasks and issues in performing their daily activities. Employer and management expectations of these workshops may not be consistent with those of employees and this gap can lead to employee pushback and even refusal to internalise and utilise the envisioned workshop key learning points that management wants them to develop. On the bases of years of professional experience as co-trainers holding soft skills development workshops and receiving employer and employee feedback on their work at dozens of multinational companies in Europe, the authors discuss critical milestones which must be met by management, in order to lay the groundwork for more successful soft skills workshops at their organisations.

KEYWORDS: employee development, soft skills, management, workshop development, employee motivation

\section{ABSZTRAKT}

\section{Sikeres és eredményes soft skill fejlesztő tréningek}

A soft skill fejlesztő tréningek segíthetik a multinacionális szervezetek különböző nyelvi háttérrel rendelkező alkalmazottai közötti kommunikáció fejlesztését a mindennapi tevékenységek ellátásához szükséges feladatokkal és felmerülő ügyekkel történő együttmüködésben. Elképzelhető, hogy a tréningekkel kapcsolatos munkáltatói és vezetői elvárások nincsenek összhangban a munkavállalókéval, amely munkavállalói ellenálláshoz vezethet, valamint a menedzsment kérése alapján fejleszteni kívánt fóbb tréningpontok elsajátításának és hasznosításának megtagadását válthatja ki.

A soft skill fejlesztő workshopokat tartó társtrénerek több éves szakmai tapasztalata és a rengeteg európai multinacionális cég munkáltatói és munkavállalói visszajelzései alapján a szerzők megvitatják mindazon kritikus mérföldköveket, amelyeket a menedzsmentnek el kell érnie annak érdekében, hogy megalapozzák a jövőben tartandó soft skill tréningek növekvő sikerét munkahelyi szervezetükben.

KULCSSZAVAK: munkaerő-fejlesztés, soft skill-ek, menedzsment, tréningfejlesztés, munkavállalói motiváció

\footnotetext{
${ }^{1}$ Egyetemi docens, Debreceni Egyetem, Gazdaságtudományi Kar, Gazdasági Szaknyelvi Kommunikációs Intézet.

${ }^{2}$ Főiskolai docens, Kodolányi János Föiskola, Angol Nyelv és Irodalom Tanszék.
} 
TEMATIKUS TANULMÁNYOK - Menedzsment: vezetők, vezetés és munkavállalók

\section{Introduction}

Management at multinational organizations focus on engaging employees to cooperate with them to achieve various targets, such as those for which a soft skills workshop would be used to prepare employees to realize. Factors which can lead to acceptable levels of employee engagement in such a workshop towards accomplishing goals set by management are many. While management can gauge indications of how best to motivate their employees via employee engagement data supplied (e.g. by their own HRM departments), communication using forums, team meetings and even direct consultations with individual employees may be the best ways to ensure that one's employees are on board before scheduling a workshop. Scientifically and experientially validated approaches exist that may lead to changes in individual employee performance, and these are supported by strategic, planned employee development and performance programs used to transform organizational cultures by transforming employee thinking and attitudes. However, any such transformative processes are by no means guaranteed of any success. Additionally, such approaches require a high degree of managerial focus, engagement and investment above and beyond what is expected of employee engagement, in order to realize the intended changes. This is particularly true for workshops focusing on soft skills, since the concrete learning outcomes and return on investment can be harder to measure and validate. In their article on reasons for training and development failure, Phillips \& Phillips (2002) highlight the importance of management reinforcement and support. Tellingly, there is a marked discrepancy in the perception of such reinforcement and support depending on the perspective. In one particular study, "[s]ome 40 percent of managers said they encouraged and coached their employees with the training, while the participants indicated that 0 percent actually provided encouragement and coaching". (Phillips - Phillips 2002: 7)

Management often attempts to use in-house surveys to determine employee attitudes and levels of engagement, but these are potentially flawed before they are even distributed. For example, do companies wish to focus on measuring employee engagement or to focus on improving employee engagement? Other potential pitfalls include viewing engagement as a survey or short-term or even one-off program, instead of as an ongoing, methodical process to achieve goals such as higher performance, supported by carefully strategized workshops after ensuring the employees are actually supportive of the planned training activities and their intended outcomes.

A recent Gallop Poll on employee engagement interpreted by Harter and Mann (2017) carefully categorizes responses into three categories: engaged, not engaged and actively disengaged. It should be noted here that organizations should not understand employee engagement to mean that percentage of employees who are not dissatisfied or are merely content with their management/employer, but 


\section{TEMATIKUS TANULMÁNYOK - Menedzsment: vezetők, vezetés és munkavállalók}

rather a state in which there is strong employee involvement in company processes which require individual and in-group commitment bolstered by a requisite level of enthusiasm necessary to effectively participate and achieve the goals set by management. Involvement, commitment and enthusiasm are three core essentials required of employees in any workshop, in order for it to have any hope of success.

\section{Knowledge management and so-called soft skills}

In deciding to request external trainers be hired to assist management in achieving specific employee developmental targets, management decides to invest a portion of a specific budget in knowledge creation, skills development and/or reinforcement. One of the advances in thinking in the management sciences in the 1990s was the increased attention to what has become referred to as a learning-based economy and its related concept of knowledge management. Changes in the characteristics of thebusiness environment thathave contributed tothisincludetheinternationalisation and globalisation of business, organisations becoming more lean, the convergence of products and services, and the fast and vast development of technology and knowledge, all accompanied by a heightened rate of change. Effective management of an organisation's knowledge assets is now recognised as a decisive factor in business success. In other words, an organisation's knowledge assets is 'centre stage'. (Davenport, De Long - Beers 1998). By the second decade of the 21st century, Drucker's (1995) prediction that knowledge would become the key economic resource and dominant source of competitive advantage can be seen to be correct. Despite the attention to the issue of knowledge management, there is as yet no agreed definition of the terms, nor consensus about approach. Management approaches (see e.g. Davenport - Prusak 1998; Nonaka - Takeuchi 1995; Sveiby 1997; Winter 1998) tend to see knowledge as processes based on individual and organisational competencies (know-how, skills, attitude). Salleh and Goh's view of knowledge management (Salleh - Goh 2002, cited in Chong 2005) emphasises that it is a process of leveraging knowledge as means of achieving innovation in process and products/services, effective decision-making, and organisational adaptation to the market for creating business value and generating a competitive advantage to organizations. It is against this theoretical backdrop that Chong (2005) seeks to identify critical enablers of knowledge management. Of the eleven such enablers that he identifies, four are particularly pertinent to this paper: employee training, employee involvement, employee empowerment and top management leadership and commitment. The first three are directly implicated in the work of external trainers, who provide the training aimed at enhancing employee involvement and activating employee empowerment; the fourth is necessary and essential enabler not only of the organisation's knowledge management, but of the success and 


\section{TEMATIKUS TANULMÁNYOK - Menedzsment: vezetők, vezetés és munkavállalók}

efficacy of the trainers' work. Chong focuses on the role of top management. In the day-to-day reality of training procurement and provision, this commitment is transmitted also through lower levels of management which may be more directly involved and affected. This paper suggests that in order for soft skills training and transfer to be effective, management's role, both direct and indirect, is crucial and often underestimated.

Organizations in industries as diverse as product manufacturing, health care, logistics, banking, automotive and IT customer service companies collectively invest millions of Euros in the development of what is known as knowledge workers. One definition of knowledge workers, supplied by Reich (1991), refers to the ability for problem-identifying, problem-solving and strategic brokering capabilities. As well as possessing higher education degrees, what classifies knowledge workers as distinct from those of past generations is their direct connectedness to and reliance on IT systems and solutions in performing everyday tasks and their overall work. Additionally, what also distinguishes today's workers from those for most of the previous century is that the level of knowledge in their specialist's area which they bring to their employers in the form of e.g. a college or university degree is now less important than ever before. Instead, the workplaces of today demand more imperative skills, including an ability to conceptualize problems and solutions and to then implement those solutions via their being entered into an IT-driven process management system. In entering the details and related data into such a system, an employee's solution to a particular problem becomes integrated into a larger, company-specific process. The solution therefore becomes one which is backed up by the name and reputation of the employer.

The ability to integrate one's ideas and answers to any of the issues which appear during one's working day into the formalities, scrutiny and rigor of i.e., a managed supplier approval, part order, customer order, product manufacturing or customer issue resolution process requires specific sets of knowledge on the employees' part. We know that Reich (1991) argued even twenty years ago that companies should emphasize the development and improvement of four basic skills: abstraction, system thinking, experimentation and collaboration. Accordingly, even before handheld 'smart' devices, tablets and laptops appeared in most workplaces, companies needed their employees to be savvy in the use of what are collectively known as soft skills, in order to be effective in their jobs. In view of the crucial nature of these skills, the term 'soft' implying a 'lighter' form of skill than 'hard skills' is, in our opinion, most misleading. Soft skills are ubiquitously needed in the exercise of any business activity, whether directly or indirectly. This is being increasingly acknowledged by management (who are themselves aware of and dependent on their own soft skills). A recent empirical study identified the top 10 such skills that executives see as essential: integrity, communication, courtesy, responsibility, social skills, positive attitude, professionalism, flexibility, teamwork, and work ethic (Robles 2012) 


\section{TEMATIKUS TANULMÁNYOK - Menedzsment: vezetők, vezetés és munkavállalók}

Soft skills integrate cognitive, communication and management skills in interacting with fellow employees (internal customers) and those outside one's own organization (external customers), and knowledge workers are more likely than other workers to use all of these skills (Béjaoui 2000). Moreover, these three groups of skills are some of the skill domains frequently identified for those working in a knowledge-based economy, as most of these workplace competencies have developed from new work organization practices brought about by technological and IT advances since the 1980s. Yet, IT alone is not the reason for the increase in the need to develop employees' knowledge bases in e.g. soft skills. Economic realities and innovations in management concepts and work organization have also contributed to the restructuring of the workplace. These changes have been and continue to be manifold in nature, including job rotation, team-based work organization, greater involvement of lower-level employees and compacted management structures. Findings from the literature demonstrate how, with new work organization practices being brought to bear, the use of different workplace competencies intensifies (Green et al. 2000).

Together with the appearance of the knowledge-based workplace environment demands rose for competencies specifically required by organizations to manage all the many changes they were forced to implement in order to adapt to IT-driven, 21st century business environments: the workforce's ability to function in an uncertain and ever-changing environment, the aptitude to successfully handle non-routine and abstract work processes, the ability to make decisions and accept the corresponding responsibilities, the ability to harmoniously function in group and interactive work situations and to support system-wide interpretations and standards (Compare Berman, Bound - Machin 1997). Berman et al. (1997) also argue in favour of improving interaction and communication skills for all workers, thus promoting strong capabilities for them to work in group situations and to provide more workers with high levels of specialized professional expertise and entrepreneurial skills, especially among middle-level professional and managerial personnel.

\section{Training needs in soft skills}

In considering the importance of developing employees further, in order to remain competitive in a knowledge-based and knowledge-driven society, both management and the external trainers it hires must take into account the fact that workers are often expected to do more than simply carry out a set of prescribed tasks. This demand relates not only to the innovation capacity of employees, but also to the ability of management to create an environment in which knowledge production and diffusion are optimized and to implement innovation in their own work, as well as in their organizations as a whole. Indeed, employees demonstrating a high degree 


\section{TEMATIKUS TANULMÁNYOK - Menedzsment: vezetők, vezetés és munkavállalók}

of innovative capacities, creativity, curiosity and a willingness and ability to question the status quo can directly contribute to the development of new knowledge and ideas for the organization to use. The potential benefits are self-evident, but the path to realization is less so. Despite carefully targeted and developed training content and delivery, studies still indicate that most of what is learned is not applied on the job. One cause may be that the environment is not adequately prepared for transfer. Without such preparation, the training efforts may fall short of achieving the objectives of the training. The role of managers in creating an appropriate transfer climate can be decisive, yet managers seem to be often unaware of their influence and would benefit from initiatives aimed at helping them to understand their own impact and at encouraging them to make changes (Phillips - Phillips 2002) The post-training environment needs to include opportunities for application, support, feedback and the modelling of behaviours. (Craig 1999) These are all areas in which supervisors can proactively positively affect transfer.

In our experience, management often focuses on the transfer of declarative knowledge and skill acquisition as the sole necessary outcomes of the trainings they order from external trainers. Yet, experience also tells us that non-behavioural factors should also be taken into consideration, especially in the understanding of how they may assist management and the trainers they engage to be able to make a distinction between the effective and non-effective performance of those employees management chose to participate in the contracted training or who signed up on their own. The term non-behavioural refers to many situations that can arise whenever social interaction occurs, and refers to situations between individuals even within groups - that are pervasive (i.e., non-episodic), such as ongoing tensions at a workplace due to unresolved issues or even recurring difficulties that inform any number of unspecified behaviours. Incompatibility between two colleagues or among several colleagues or opposition to a new boss or rule is a persistent element that endures over time and involves (mis)perceptions that generate individual episodes of conflict, which are then behavioural, as these play themselves out also on the basis of how individuals behave in confrontational situations. (Compare Appelberg et al. 1996 and Jehn - Bendersky 2003)

Knowledge of the existence of such non-behavioural factors at a workplace, especially within and/or among members of the group of employees to be trained, is crucial for external trainers. Without it, their ability to assist employees to be trained to be able to meet new performance requirements management will be making on their work becomes practically impossible. In other words, the basis for contracting the external trainers loses all foundation. Examples of these factors, in the case of non-behavioural factors, which specifically undermine the effectiveness of external trainers during a workshop, consist of the degree of an employee's (un)willingness to work in collaboration with co-workers or as a part of a team. Another example of such a factor could be the same employee's readiness to serve in a coordinating 


\section{TEMATIKUS TANULMÁNYOK - Menedzsment: vezetők, vezetés és munkavállalók}

role in a task during a workshop which that employee had hitherto felt unprepared to do. Common examples we also meet at the companies we have trained at include employee (un)willingness to accept new or replacement technologies, company names and logos, as well as their (un)willingness to focus on the customer, instead of on a process or company 'norm'. Equally important, we also identify as outcomes of our training work the overarching need for those employees who we are training to be receptive to the need to be trained, in order to meet new work or managerial demands and for them to be able to recognize for themselves just how vital their acquisition and proper use of the key learning points we provide them are for their continued success in their positions. For some participants, the knowledge we impart to them may be vital for their career advancement.

\section{The foreign language component}

Globalization intensifies the importance of any business organization to have a strong international orientation. Within any multinational company, employees not only require a strong command of the sector-specific and company-specific jargon in their mother tongues, but equally need to demonstrate competency in the usage of such jargon in one or more foreign languages. Furthermore, employees at such organizations must not only be able to understand and empathize with counterparts from other cultures, they must be able to convince their colleagues that they are capable of meeting their needs. (Compare Fritz et al. 2010)

That having been said, none of these abilities are a given and employees should not be left on their own in learning their use or in honing related skills. Organizations therefore must promote an in-house culture which assists its employees to be open to deepening their foreign language knowledge, as well as ensure means for them to further maintain and develop their sector-specific and company-specific foreign language jargon, languages and intercultural competencies. External trainers are a key vehicle for ensuring this happens, especially when the trainers are native speakers with relevant experience and knowledge.

The key to the success of any such training lies in management's working to prepare the ground for the external trainers, especially in those cases in which the employees are hesitant or even resistant to receiving the training on offer in another language than the employees' native tongue. The willingness to become cognitively receptive to accepting the parity of the importance of foreign language command with the employees' command of their areas of expertise in guaranteeing task fulfilment by contractors or negotiating in considerably stressful situations using e.g. English as the language of communication. Certainly, without the refining of the essential linguistic skills needed for effective and successful communication using a 


\section{TEMATIKUS TANULMÁNYOK - Menedzsment: vezetők, vezetés és munkavállalók}

foreign language in the workplace with colleagues, suppliers and customers, business opportunities may be lost or even left unexplored through misunderstanding, failure to understand or out-and-out incompetence.

\section{Competence}

As well as cognitive skills, the workplace also demands non-cognitive and 'soft' skills, such as interpersonal skills, persistence and communication skills. While such skills cannot always be measured in any objective manner (or only with unfeasible expenditure of effort and cost), the literature does discuss them quantifiably in terms of how well an employee puts them to use. This is called competence. Francoise Delemare Le Deist and Jonathan Winterton J. (2005) discuss the prevalent definitions and usage of the term competence in great detail in the context of training activities at business organisations in the USA, UK, France and Germany. As the literature on how best to define this term is too broad for inclusion in this paper, we refer to their discussion, especially as it attempts to holistically clarify the concept of competence by incorporating knowledge, skills and competences. Returning to our own discussion, the term 'competence' is often used to indicate the combination of knowledge, skills and behaviour needed to improve on the job performance of an employee. In terms of competence, in any case in which an employee is on possession of exactly the right combination of knowledge, skills and behaviour to obtain the expected level of performance on the job, one may consider that employee to be competent. The term competence stresses the need to be able to utilize a combination of skills and characteristics, in order to become and stay competent at work. While it is true that any employee is in possession of a wide range of characteristics, it is also true that some of these will weaken and others will strengthen that employee's performance on any given day or in a specific situation. An employee's strong characteristics might be able to compensate for that employee's weak ones, but not always. For management, the ability of an employee to grow into a job over time or to meet - and even exceed - the requirements of a job over time, poses a challenge to which management must be able to react. For management to be capable of adjusting the competences of any employee to meet new targets or to qualify that employee for a new position within the organization, management must provide some kind of training or learning opportunity. Failure to develop the workforce in a company is a failure of management.

Research tells us that employee competencies encompass those talents, skills and capabilities that contribute to multi-factor productivity gains and which are necessary for the sustainable economic growth and development of an organization (Hartog 2001; Sianesi - Van Reenen 2003). However, it must be noted that research 


\section{TEMATIKUS TANULMÁNYOK - Menedzsment: vezetők, vezetés és munkavállalók}

is not uniform as to how to classify competencies. Heijke, Meng - Ramaekers (2002), distinguish three groups of competencies: those acquired in school and are then used in the workplace; those acquired in school, which assist workers to gain new competencies on-the-job; and those acquired mainly in a working context. Kellermann (2007) classifies competencies into five groups: academic, general-academic, scientific-operative, personal-professional, social-reflexive, and physiological-handicraft. Earlier, Bunk (1994) aggregated these competencies into four different groups: specialized, methodological, participative and socioindividual. Other classifications are added depending on the data available (Allen - Van der Velden 2001). Thus, there is no general agreement about competency classifications, and economic theory does not provide any clear categorization.

Organizational competencies refer to the ability to work under pressure, to work independently and with attention to detail. Specialized competencies require an ability to carry out activities and tasks responsibly and competently and presume that the specialized individual possesses the required knowledge and skills to successfully do so. Methodological competencies include the ability to react to problems appropriately, using prescribed procedures and being able to find functional solutions to problems, based on experience. Generic competencies may be applied in many different contexts. Such competencies include critical thinking skills, as well as (in)formal communication skills. Participative competencies include those involving planning, accepting tasks in a positive manner, decision-making and even the willingness to assume responsibilities. Team-oriented behaviour and interpersonal empathy belong to the sphere of socio-emotional competencies. All these fall under the purview of soft skills training.

\section{Motivation and effectiveness}

In the field of foreign language learning and teaching, motivation has long been recognised as a crucial factor in success. In their seminal work, Gardner \& Lambert (1972) proposed a framework for understanding the differing motivations that learners bring to their study of a foreign language, distinguishing between instrumental and integrative motivation. Essentially these terms answer the question of why learners want to learn a language. In the case of instrumental motivation, they have a practical reason linked to potential utilitarian gains, such as meeting a requisite for admission to tertiary education, facilitating their travels or because they need the language knowledge for their job. Integrative motivation, on the other hand, focuses on learning a language to better understand and get to know the people who speak the language and their culture, i.e. for personal reasons, such as heritage or marrying someone from another culture or because they want to read 


\section{TEMATIKUS TANULMÁNYOK - Menedzsment: vezetők, vezetés és munkavállalók}

the works of a particular author in the original. The link to intrinsic motivation ("motivation to engage in an activity for its own sake" (Pintrich - Schunk 2002: 245) and extrinsic motivation ("motivation to engage in an activity as a means to an end" (Pintrich - Schunk 2002: 245) is clear, as is the applicability of the constructs to business soft skills training outcomes. Extensive research on these forms of motivation has validated their usefulness and tended to support intrinsic or integrative are being the more highly valued form of motivation, especially in educational settings. In business settings, however, the focus has been rather on extrinsic or instrumental motivation for immediate actions taken because of an expectation that they will lead to the achievement of future goals. In addition, there has been a growing recognition that people can be both motivated in the several ways at the same time, and that the interplay of these components is not necessarily additive over time (See Lepper - Greene 1978). In fact, deliberate interventions in consequences, such as rewards, can lead to a decrease in intrinsic motivation to perform the behaviour (even if it they positively affect the occurrence of the behaviour). In this context, the Self-Determination Theory put forward by Deci and Ryan offers a somewhat different approach. Focusing on the three innate psychological needs that they see as universal, namely competence, autonomy and relatedness (Ryan - Deci 2002), they distinguish two types of motivation: autonomous and controlled, emphasising that the quality of motivation is more important than the amount of motivation. Whilst an intrinsically motivated action is by definition autonomously motivated with the perceived locus of causality internal, extrinsically motivated actions are more complex. Four different types can be identified depending on the degree of relative autonomy, with integrated regulation being the qualitatively best type (Deci - Ryan 2002). In this case the external reason for the activity is fully assimilated with the self and the self's core values. The desirability of such motivation for work situations raises the question of what affects it. Numerous field and laboratory studies suggest autonomy as being the most important facilitator of integration. Support for autonomy stems from social context and interpersonal ambience. Furthermore, in the case of autonomous extrinsic motivation "internalization is facilitated by explicit or implicit endorsement of behaviours by significant others". (Gagné - Deci 2005, 339) The implication for businesses is therefore that the motivational environment in which the employees work affects the employees' motivation for training. Most specifically, the behaviour and attitude of the manager can support the development of integrated regulation. Such optimal motivation in turn affects the degree of transfer - which is the real goal of any training programme. While management decisions have direct implications on how external trainers design and deliver workshops, their impact may be limited before the ordered workshop has even begun. One of the reasons for such limitation may be found whenever there is a disconnect between management and participant 


\section{TEMATIKUS TANULMÁNYOK - Menedzsment: vezetők, vezetés és munkavállalók}

(employee) perception, attitude, motivation and ability. As one example, Kim et al. (2015) report on trainee attitudes toward an organization as determinative to the effectiveness of any workshop, based on their research into Korean employees. The research of Tannenbaum \& Yukl (1992) is considered to be ground-breaking in their examination of trainee motivation, but they also attempted to qualify the effectiveness of any workshop by investigating such elements as the locus of the workshop, the media used by the trainers, the sequence of materials or even that of their contexts. Psychologists inform us that any study of motivation is even more complex. Kanfer (1990: 78-9), for example, reminds us how "motivation is not directly observable", and discusses three critical components of motivational outcomes in the workplace, "direction, intensity and persistence of effort". Motivation, as a complex, opaque determinant force, acting on and even against management intention, workshop content and design, trainer delivery and overall workshop effectiveness, belies an understanding of the human (employee) psyche and attitude at around the time a workshop will be delivered. Motivation, in this sense, encompasses the divergence of human intentions, managerial and trainee (employee) goals, trainee behaviour and trainee performance - all affecting the outcome of management strategies for employee "development, learning and their performance of complex, sequential behaviour patterns" (Kanfr 1990: 82). Tannenbaum \& Yukl (1992) also emphasize how individual and situational characteristics may impact training motivation. Colquitt \& LaPine (2000) discuss the elements of achievement motivation, job involvement, organizational (also: career) commitment, career exploration and planning, as well as self-efficacy are all individual characteristics affecting training motivation among participants.

Workshops are normally held to various groups, either to teams selected by management for a specific developmental purpose towards a strategic goal or to a diverse group of employees who volunteer (sign-up) to a training option of their choice, for their own reasons. Both situations can have a positive effect. If an employee signs up voluntarily, possibly even having to lobby their supervisor for support or permission to attend, this makes a positive attitude likely. When employees have no choice and have to attend a training, this can result in lower motivation to learn; however, the opposite effect could also be possible: the perceived value of the training could be enhanced by the evident importance that management attaches to it. (Machin - Treloar 2004) Regardless, groups being trained are made up of individuals; therefore, individual differences certainly impact group functioning during the training itself. As individuals differ in so many ways, management and trainers must understand how these differences may significantly the outcome of the workshop, both for the individual and the target group as a whole. These differences include personality, level of experience and expertise in a professional area (in)directly related to the workshop content, general mental ability, personal/ 


\section{TEMATIKUS TANULMÁNYOK - Menedzsment: vezetők, vezetés és munkavállalók}

career motivation and values. There are additionally also significant implications of culture on how well the target group will work together. Research has shown how culture, specifically individualism and power distance, may actually weaken the relationship between directive management and behaviours across groups from different cultures (Euwema, Wendt, - van Emmerik 2007). As multinational organizations frequently order workshops in which participants come with mixed cultural diversity, it is also important to understand how and why cultural diversity influences target group processes affecting the outcome of a particular training. (Inter)cultural research into this element of understanding training effectiveness will become crucial, as the prevalence of multicultural target groups in multinational organizations increases.

\section{Effectiveness}

The measure of training effectiveness has become associated with Kirkpatrick's (1967) hierarchical model of training. Although it has been criticized for being vague and for the lack of causal relation between the levels (See Alliger et al. 1997) the model continues to be widely used due to its relevance and suitability for evaluating training programmes in a structured, organized way. The model identifies fours levels of training outcomes: reaction, learning, behaviour, and results. Essentially, these four levels related to satisfaction (reaction), learning, application (behaviour) and business impact (results). External trainers are often limited to collecting the reactions, that is, the feelings and impressions, of the participants after the training, usually directly at the end of the session. Whilst this is valuable information, revealing what the participants felt about the programme and how useful they consider it to be, it is still the lowest of the levels in the Kirkpatrick hierarchy. The next level, learning, can also be assessed, to some degree, in the course of the sessions. Nevertheless learning logically also requires later assessment, for longerterm retention. As for behaviour and results, these are arguably the most important outcomes of training but are harder to define, identify and collect data on. From the point of view of the organization, the training becomes valuable if it contributes to the achievement of business objectives, if it is aligned with business needs. These two levels - behaviour and results - are external to the training itself and beyond the scope of what external trainers can usually hope to affect. Yet, they are crucial for the success of the training and the work of external trainers is greatly helped by measures taken in-company to ensure that training has the right focus and direction, and can be developed so as to be in line with specified business objectives. 


\section{TEMATIKUS TANULMÁNYOK - Menedzsment: vezetők, vezetés és munkavállalók}

\section{Conclusions}

In closing, on the bases of all the issues and elements discussed above, we would make the following suggestions to any business organization's management whenever contracting external trainers to assist in employee development. These suggestions are broken down into four groups, as follows: 1) Attitude - This is the most crucial element that management often needs to change, when contracting external trainers. We do not question the expertise, knowledge or know-how of those hiring us to hold employee development workshops. We do not pretend to be engineers, lawyers, bankers, quality control experts or logistics managers, but we are experts at what we do. External trainers need to be treated with the same respect and courtesy that we bring with us to the company at which we will be holding our workshops. While we understand that there are some individuals offering similar services who are not qualified to do so, we are capable of proving our worth, in demonstrations, if necessary. This means that management needs to serve the external trainers as a kind of goodwill ambassador to the employees. Questioning the abilities or knowledge of the external trainers in front of employees to be trained is to sabotage the workshop before it is held. 2) Communication - Learning content management (LCM) can only be done well by ensuring honest, open and continual communication with the external trainers. External trainers need to know and understand those issues between management/the company and employees which might impinge on the successful outcome of the key learning objectives of the planned workshop. Discussions with external trainers should also deliberate on how to handle conflicts/issues between the various business units to be represented by individual participants in the workshop. External trainers should also be aware of what issues to avoid mentioning or allowing discussion on during the workshop. Similarly, management policy/stand on some foreseeable potentially sensitive issues should be clarified ahead of time. External trainers need to be aware of the company's core values and how these are manifested (and are expected to be manifested) in daily practice. 3) Organizational Needs Management - As employee development and training are necessities for any business organization, management needs to ensure that it lays the foundation for the training with its employees beforehand and ensure positive reinforcement of the learning objectives after the training has been held. This can be formalised in a set of actions to be taken before and after the workshop (such as pre-work, pre-workshop briefings, post-work, postworkshop briefings) While some managers and employees may feel that the development, management and delivery of any training is rather a distraction, by developing a sound working relationship with external trainers to hold series of workshops and managing the content in collaboration with them, management will better serve the core needs of their operations. 4) Mitigate Business Risks - Without training in soft skills, management is placing its company's business at risk. 


\section{TEMATIKUS TANULMÁNYOK - Menedzsment: vezetők, vezetés és munkavállalók}

Workshops benefit companies by helping to protect them from the liabilities of losing customers and their hard-won reputations, if they do not periodically provide the right training to their employees. External trainers enter a company with an objective ear and eye: they can often recognize potential behavioural and attitude problems employees or business units have that management misses, offer workshop participants guidance and solutions, practice using remedies in role plays and exercises, and then communicate identified problems and the remedies offered during the workshop back to management. In other words, training reduces business risk and can inform management of potential trouble.

In closing, soft skills development workshops ordered by management can serve to improve their organisations in diverse ways. The expectations participants and management have of these workshops may diverge in significant ways. Without employee interest and active engagement in the learning opportunity, the outcomes of the workshops may fall short of management's objectives. Indeed, if managers do not succeed in communicating their expectations successfully to their employees, pushback can undermine the entire endeavour. By working together with external trainers as partners and not as outsiders, management can maximize the benefits of the workshops they contract. In doing so, management must be attentive to resistance, pushback and attitudes among employees foreseen as participants and strive to create the necessary climate in the office before a workshop is held. Managers must explicitly lend both the trainers and the workshop itself crucial support by ensuring adequate information flow and that positive messages about the trainers, the training program and the expected outcomes of the workshop are provided to employees. Through the establishment of a functioning partnership, external trainers and what they provide organizations will assist management to obtain smoother business operations through better prepared employees and be able to better deliver expected key learning and developmental content during the workshop itself.

\section{References}

Allen, J. - Van der Velden, R. (2001): Educational mismatches versus skill mismatches: Effects on wages, job satisfaction and on-the-job search. Oxford Economic Papers, 53(3), 434-452.

Alliger, G.M. - Tannenbaum, S.I. - Bennett, W. - Traver, H. - Shotland, A. (1997): A meta-analysis of the relations among training criteria. Personnel Psychology, 50, 341-358.

Appelberg, K. - Romanov, K. - Heikkilä, K. - Honkasalo, M. - Koskenvuo, M. (1996): Interpersonal Conflict as a Predictor of Work Disability: A Follow-Up Study of 15,348 Finnish Employees. Journal of Psychosomatic Research, 40, 157-167. 


\section{TEMATIKUS TANULMÁNYOK - Menedzsment: vezetők, vezetés és munkavállalók}

Béjaoui, A. (2000): Sur la mesure des qualifications: application à l'émergence de l'économie du savoir, Ottawa: Human Resources Development Canada.

Berman, E. - Bound, J. - Machin, S. (1997): Implications of skilled-biased technological change: International evidence. NBER working paper No. 6166, National Bureau of Economic Research, Cambridge, MA.

Bunk, G. P. (1994): Teaching competence in initial and continuing vocational training in the Federal Republic of Germany. Vocational Training European Journal, 1, 8-14.

Chong S. C. (2005): Critical Factors in the Successful Implementation of Knowledge Management, Journal of Knowledge Management Practice, June 2005, 1-9.

Colquitt, J. - LaPine, J. A. (2000): Toward and integrative theory of training motivation: A meta-analytic path analysis of 20 years of research. Journal of Applied Psychology, Vol 85, No. 5, 678-707.

Craig, S. I. (1999): Transfer of training. Online Notes to: Seminar in Industrial Psychology. http://www.geocities.ws/rpipsych/transferoftraining.html. Accessed 1 August 2017.

Davenport, T. - De Long, D. - Beers, M. (1998): Successful knowledge management projects. Sloan Management Review, 39(2), 43-57.

Davenport, T. H. - Prusak, L. (1998): Working knowledge: How organizations manage what they know. Boston, Mass: Harvard Business School Press.

Delemare Le Deist, F. - Winterton J. (2005): "What is competence?" Human Resource Development International, Vol. 8, No. 1, 27 - 46. DOI: $10.1080 / 1367886042000338227$.

Drucker, P. (1995): Managing in time of great change. New York: Truman Talley Books.

Euwema, M.C. -Wendt, H. - Van Emmerik, IJ. H. (2007): Leadership styles and group organizational citizenship behavior across cultures. Journal of Organizational Behavior. 28, 1-23.

Fritz Mocsáriné, J. - Hajdú, Z. - Juhász, Cs. - T. Wiwczaroski (2010): Harmonizing (L2/SP) competencies with labour market needs. ESPWorld. I (27), Vol 9. http://www.esp-world.info/Articles_27/FRITZ_HAJDU_WIWCZAROSKI2009. pdf. Accessed 5 July 2017.

Gagné, M. - Deci, E. L. (2005) Self-determination theory and work motivation. Journal of Organizational Behavior. 26, 331-362.

Gardner, R. C. - Lambert, W. E. (1972): Attitudes and motivation in second language learning. Rowley, MA: Newbury House.

Green, F. -Ashton, D. - Felstead, A. (2000): “Estimating the Determinants of Supply of 


\section{TEMATIKUS TANULMÁNYOK - Menedzsment: vezetők, vezetés és munkavállalók}

Computing, Problem-Solving, Communication, Social and Team-working Skills", Paper presented at the Seminar "Skills Measurement and Economic Analysis", 27-29 March, 2000, University of Kent at Canterbury, Canterbury.

Harter, J. - Mann A. (2017): The Right Culture: Not About Employee Happiness. Business Journal. April 12, 2017 edition.

http://www.gallup.com/businessjournal/208487/right-culture-not-employeehappiness.aspx?g_source=employee+engagement\&g_medium=search\&g campaign=tiles. Accessed 1 August 2017.

Hartog, J. (2001): On human capital and individual capabilities. Review of Income and Wealth, 47(4), 515-540.

Heijke, H. - Meng, C. - Ramaekers, G. (2002): An investigation into the role of human capital competencies and their pay-off. Research Memorandum. Maastricht:ROA.

Jehn, K. A. - Bendersky, C. (2003): Intragroup Conflict in Organizations: A Contingency Perspective on the Conflict-Outcome Relationship. Research in Organizational Behavior, 25, 187-242. http://dx.doi.org/10.1016/S0191-3085(03)25005-X.

Kanfer, R. (1990): Motivation theory and Industrial/Organizational psychology. In: Dunnette, M.D. - Hough, L. (Eds.), Handbook of industrial and organizational psychology. Volume 1. Theory in industrial and organizational psychology. Palo Alto, CA: Consulting Psychologists Press, 75-170.

Kellermann, P. (2007): Acquired and required competencies of graduates. In: Teichler, U. (Ed.), Careers of university graduates: Views and experiences in comparative perspectives. Dordrecht: Kluwer, 115-130.

Kim, S. - Hahn H. J. - Lee, J. (2015): Organizational Attitudes as Precursors to Training Performance. Human Resource Development Quarterly, 26/4, Winter 2015, 409-429.

Kirkpatrick, D. L. (1967). Evaluation of training. In Craig, R. L. - Bittel, L. R. (Eds.), Training and Development Handbook. New York: McGraw-Hill, 87-112.

Lepper, M. R. - Greene, D. (1978): (Eds.). The hidden costs of reward. Hillsdale, NJ: Erlbaum.

Machin, M. A - Treloar, C. (2004): Predictors of motivation to learn when training is mandatory. In: Katsikitis, M., (Ed.), Proceeding of the 39th APS Annual Conference. Australian Psychological Society, Melbourne, Victoria, Australia, September, 157161.

Nonaka, I. - Takeuchi, H. (1995): The knowledge creating company: How Japanese companies create the dynamics of innovation. New York: Oxford University Press.

Phillips, J. J. - Philips, P. P. (2002): Eleven reasons why training and development fails... and what you can do about it. Training, 39(9), 1-10. 
www. metszetek.unideb.hu

\section{TEMATIKUS TANULMÁNYOK - Menedzsment: vezetők, vezetés és munkavállalók}

Pintrich, P. R. - Schunk, D. H. 2002): Motivation in education: Theory, Research, and Application2nd ed.) New Jersey: Merrill Prentice Hall.

Reich, R. (1991): The Work of Nations. Simon and Schuster, New York.

Robles, M. M. (2012): Executive Perceptions of the Top 10 Soft Skills Needed in Today's Workplace. Business Communication Quarterly 75(4) 453-465.

Ryan, R. M. - Deci, E. L. (2002): Self-determination theory and the facilitation of intrinsic motivation, social development and well-being. American Psychologist, $55,68-78$.

Salleh, Y. - Goh, W. K. (2002): Managing human resources toward achieving knowledge management. Journal of Knowledge Management, 6(5), 457-468.

Sianesi, B. - van Reenan, J. (2003): The Returns to Education: Macroeconomics. Journal of Economic Surveys, vol. 17, issue 2, 157-200.

Tannenbaum, S. I. - Yukl, G. (1992) Training and development in work organizations. Vol.43:399-441.

Sveiby, K. (1997): The New Organisational Wealth. San Francisco: Berrett-Koehler.

Winter, S. (1998): On course, competence and the corporation. Journal of Law, Economics and Organisations, 4(1), 163-180. 